\title{
In-Place Oil Shale Resources of the Mahogany Zone, Green River Formation, Sorted by Grade, Overburden Thickness, and Stripping Ratio, Piceance Basin, Colorado, and Uinta Basin, Utah
}

A range of geological parameters relevant to mining oil shale have been examined for the Mahogany zone of the Green River Formation in the Piceance Basin, Colorado, and Uinta Basin, Utah, using information available in the U.S. Geological Survey Oil Shale Assessment database. Basinwide discrete and cumulative distributions of resource in-place as a function of (1) oil shale grade, (2) Mahogany zone thickness, (3) overburden thickness, and (4) stripping ratio (overburden divided by zone thickness) were determined for both basins on a per-acre basis, and a resource map showing the areal distribution of these properties was generated. Estimates of how much of the Mahogany zone resource meets various combinations of these parameters were also determined. Of the 191.7 billion barrels of Mahogany zone oil in-place in the Piceance Basin, 32.3 percent (61.8 billion barrels) is associated with oil shale yielding at least 25 gallons of oil per ton (GPT) of rock processed, is covered by overburden 1,000 feet thick or less, and has a stripping ratio of less than 10. In the Uinta Basin, 14.0 percent (29.9 billion barrels) of the 214.5 billion barrels of Mahogany zone oil in-place meets the same overburden and stripping ratio criteria but only for the lower grade cutoff of 15 GPT.

Total oil shale resources in the Eocene Green River Formation of the Piceance and Uinta Basins in Colorado and Utah amount to an estimated 2.845 trillion barrels of oil inplace regardless of grade according to the most recent U.S. Geological Survey (USGS) assessment (Johnson and others, $2010 a, b)$. This total value does not represent how much of the resource is likely to be recoverable, because much of the oil shale is of insufficient grade (as determined by yield in gallons per ton [GPT] of oil generated per ton of rock processed) or occurs in intervals too thin to be targeted for development. The overall oil shale interval in the Piceance and Uinta Basins is subdivided, in most areas, into 17 stratigraphically defined, alternating "rich" and "lean" zones (Donnell and Blair, 1970; Cashion and Donnell, 1972; Johnson and others, 2010a,b). The Mahogany zone, the subject of this report, is the most widespread and richest oil shale zone in both basins and has been the target of most oil shale extraction projects. The Mahogany zone was deposited during the greatest expanse of Eocene Lake Uinta, a long-lived lacustrine system that produced the oil shale in Colorado and Utah, and is located near the top of the oil shale interval in the Parachute Creek Member of the Green River Formation.

The Fischer assay method was used to determine oil shale grade (American Society for Testing and Materials, 1980). Briefly, Fischer assay pyrolysis involves heating a 100-gram aliquot of crushed oil shale ( -8 mesh; less than $[<] 2.38$ millimeters or $<0.0937$ inches) from ambient temperature to 500 degrees
Celsius $\left({ }^{\circ} \mathrm{C}\right)\left(932\right.$ degrees Fahrenheit $\left.\left[{ }^{\circ} \mathrm{F}\right]\right)$ at a rate of $12{ }^{\circ} \mathrm{C}$ per minute (40-minute heating time) and maintaining that maximum temperature for 20 minutes or until oil generation ceases. Pyrolysate oil and water is collected using a condenser chilled to $<5^{\circ} \mathrm{C}$, and the total amount of gas generated is determined by the difference between the original weight of the oil shale and the total weight of the recovered products (spent shale, oil, and water). Data summarizing Fischer assay analyses conducted on Piceance and Uinta Basins oil shale are included in reports that accompany the most recent USGS assessments for these basins (Johnson and others, 2010a,b).

The only proven approach for large-scale commercial use of oil shale to date has been to mine and then process the oil shale on the surface by either burning it to generate electricity or by retorting the rock to produce shale oil. Extracting petroleum from oil shale requires heating the rock to high temperatures (350 to $500{ }^{\circ} \mathrm{C}$ [662 to $932{ }^{\circ} \mathrm{F}$ ] or higher) in order to convert sedimentary organic matter (kerogen) into oil and gas. Pyrolysisbased approaches (heating in the absence of oxygen) for extracting petroleum from oil shale can be applied at above-ground processing facilities or by heating shale underground using a variety of different schemes (in situ retorting). Above-ground retorting uses well-established technologies that have been implemented in the United States and other countries. This approach requires that oil shale be mined and crushed before it can be processed. The feasibility of oil shale mining is determined by economic, technological, and geological considerations. 
Different mining approaches could be utilized to develop Mahogany zone oil shale in the Piceance and Uinta Basins. The two most often cited are open-pit for surface mining and roomand-pillar for underground mining (Baughman, 1978; Speight, 2012). Open-pit mining has the benefit of high recoveries ( 90 percent) and relative simplicity in application. However, the applicability of open-pit mining is expected to be limited to situations where the overburden thickness is less than 150 feet (ft) and the stripping ratio is close to 1:1 (Speight, 2012). Room-andpillar mining involves excavations of large blocks of oil shale (rooms) while leaving pillars behind to support the mine roof. This approach is used extensively in coal mining and has been shown to be a viable method of extracting oil shale (Baughman, 1978). Underground mining by the room-and-pillar approach has been tested in the Piceance Basin by the former U.S. Bureau of Mines at Anvil Points (approximately 9 miles west of Rifle, Colorado) and by ExxonMobil at the Colony Mine (approximately 12 miles north of Parachute, Colorado). Disadvantages for room-and-pillar mining include the high cost and low recoveries ( $<60$ percent).

Environmental impacts of an oil shale industry focused on mining and surface retorting are expected to include (1) extensive land disturbance, particularly in the case of surface mining; (2) the disposal of large quantities of spent shale; (3) potential for leaching organic and inorganic pollutants from spent shale piles and contaminating surface and groundwater supplies; (4) high water use, estimated to range between 2 to 5 barrels of water needed per barrel of oil produced (Office of Technology Assessment, 1980); and (5) air-quality impacts due to emissions. Approximately 32 million tons of 25-GPT oil shale would have to be mined and processed daily to generate the approximately 19 million barrels of oil used in the United States each day (Speight, 2012). It has been projected that the scale an oil shale industry in the Western United States could reasonably reach in a few decades might produce about one million barrels of oil per day (Bartis and others, 2005), requiring mining of about 1.7 million tons of oil shale and disposal of about 1.4 million tons of spent shale. Herein, we address the geological parameters relevant to the mining-based development of the Mahogany zone oil shale of the Parachute Creek Member of the Eocene Green River Formation in the Piceance and Uinta Basins of Colorado and Utah.

The Mahogany zone is a primary target for mining development because of its (1) high average oil yield or grade determined using Fischer assay, (2) thickness, and (3) limited overburden in many areas. Figures 1 and 2 show distributions of Mahogany zone in-place oil resource for the Piceance and Uinta Basins, respectively, sorted by properties relevant to mining as discussed below. The plots show discrete (bars) and cumulative (solid lines) distributions with the median, or property value that represents 50 percent of the total cumulative resource, indicated by a vertical dashed line.
The median grade of Piceance and Uinta Basins Mahogany zone oil shale (per-acre basis, rounded to the nearest integer) is 24 GPT and 13 GPT, respectively. Oil shale grade distributions for the Piceance and Uinta Basins are shown in figures $1 A$ and $2 A$, respectively. The thickness of the Mahogany zone in the Piceance and Uinta Basins is another key factor making it a preferred development target, particularly for mining. The median thickness of the Mahogany zone in the Piceance and Uinta Basins is $148 \mathrm{ft}$ and $106 \mathrm{ft}$, respectively, and histograms for each basin showing total in-place Mahogany zone resource as a function of zone thickness are presented in figures $1 B$ and $2 B$. Isopachs showing variations in thickness of the Mahogany zone are plotted on the map of the two basins (fig. 3).

The overburden thickness is an important parameter because it may be impractical to remove or mine through very thick overburden $(>1,000 \mathrm{ft})$ to reach moderately valuable ore or resource rocks regardless of the thickness of the targeted resource or pay zone. The median overburden thickness overlying the Mahogany zone in the Piceance and Uinta Basins is approximately $800 \mathrm{ft}$ and $1,900 \mathrm{ft}$, respectively (figs. $1 C, 2 C$ ). The stripping ratio (sometimes called pay ratio; dimensionless) is the overburden thickness divided by the thickness of the resource or pay zone. Total in-place resource within the Mahogany zone as a function of stripping ratio for the two basins is shown in figures $1 D$ and $2 D$ and ranges of the stripping ratio are shown as color contours on the map in figure 3 . Median stripping ratios for the resource in Piceance and Uinta Basins are 5 and 17, respectively.

Geographic information systems and business intelligence technologies were used to calculate values shown in the histograms (figs. 1 and 2) relating oil shale grade (in GPT), zone thickness (in feet), and overburden thickness (in feet) for the Mahogany zone averaged on a per-acre basis to total oil in-place in barrels per acre. The resolution of the analysis is constrained by the data density and stratigraphic interpretation of zone tops using well logs, core descriptions, and Fischer assay oil-yield histograms.

Previous assessment reports included individual maps showing areal distributions of grade, thickness (Johnson and others, 2010a,b), and overburden thickness on the top of the Mahogany zone (Mercier, 2010a,b). These parameters have been incorporated into figure 3 , which shows stripping ratios (color contours), zone thicknesses (isopachs), and areas with grade cutoffs of 15 GPT (surrounded by thick red line) and 25 GPT (shaded area within Piceance Basin) for the Mahogany zone. Combining these properties on the same map makes it possible to identify the most prospective oil shale mining areas in the Piceance and Uinta Basins. Table 1 contains specific resource values for both basins that meet selected criteria based on these properties.

The Mahogany zone has been mined around much of the perimeter of the Piceance Basin in the past, whereas mineable 
$\boldsymbol{A}$

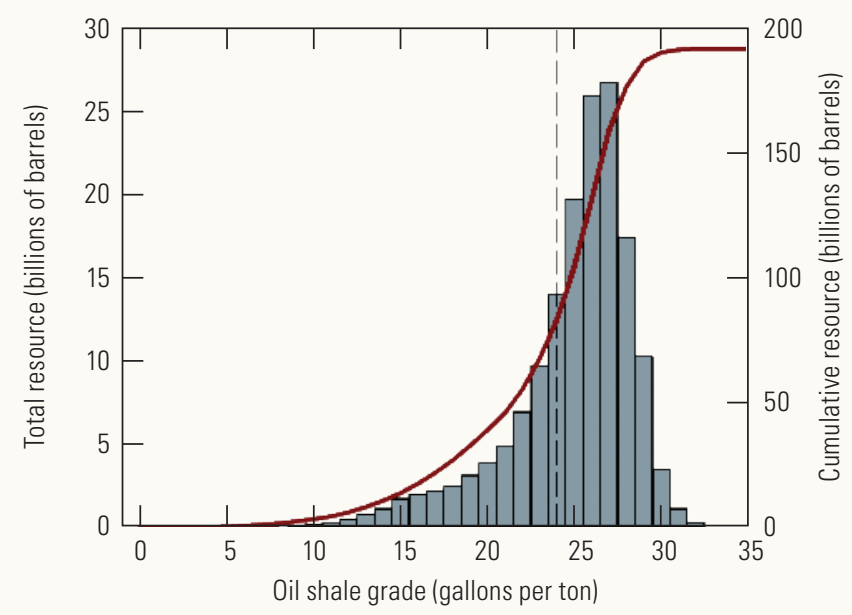

C

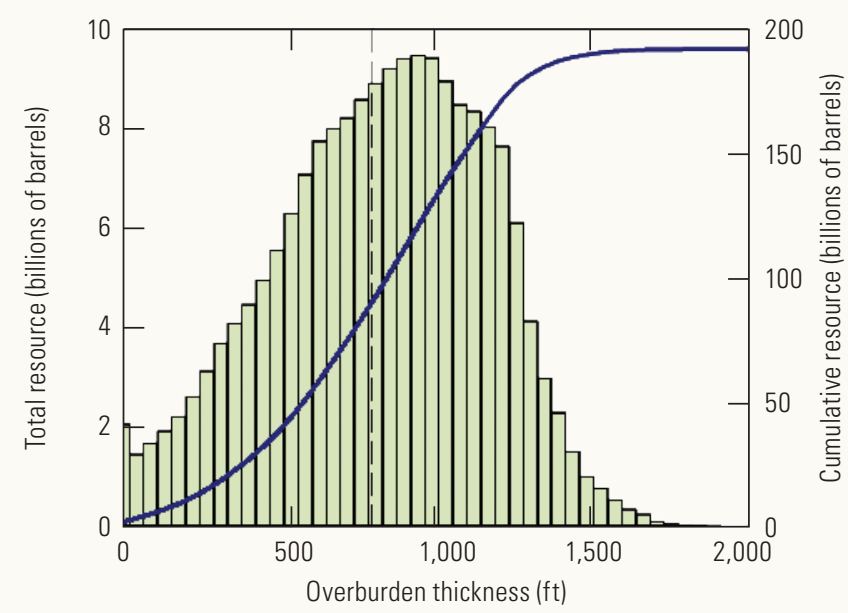

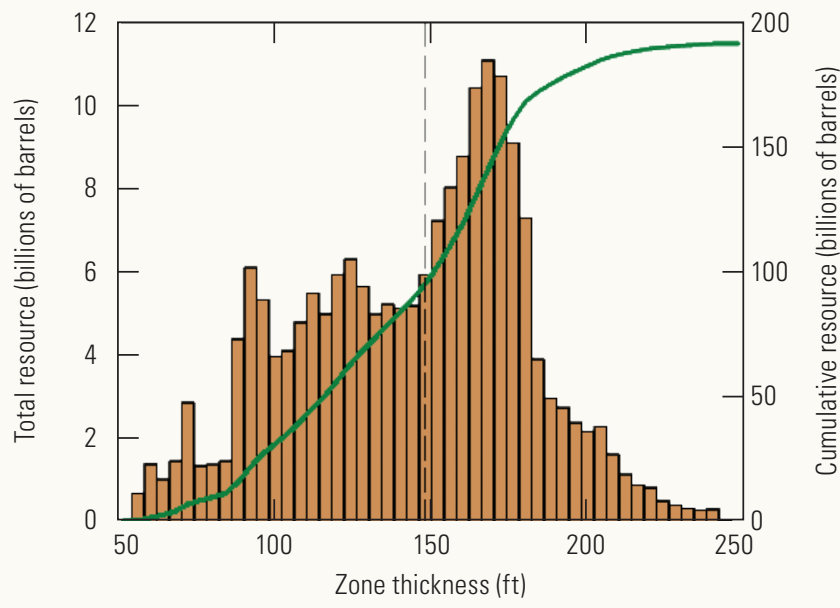

D

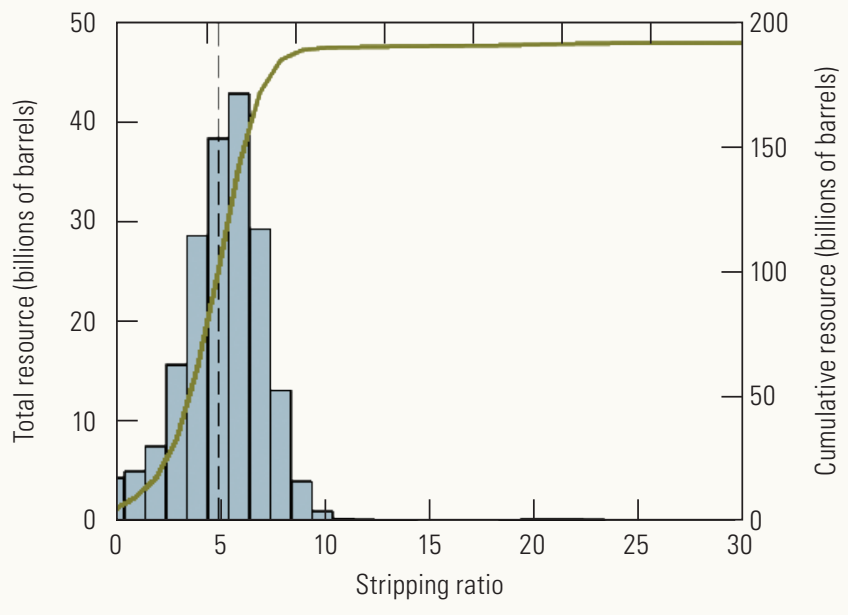

Figure 1. Histograms showing discrete (bars, left vertical axes) and cumulative (thick lines, right vertical axes) distributions of Piceance Basin in-place oil shale resource for the Mahogany zone sorted by $A$, grade (in gallons per ton); $B$, zone thickness (in feet [ft]); $C$, overburden thickness (in feet); and $D$, stripping ratio (dimensionless). Dashed lines mark the median property value for each distribution, determined at 50 percent of the total cumulative resource of 191,729,795,981 barrels of oil.

oil shale in the Uinta Basin is located mainly in the eastern part of the basin, near the Colorado-Utah border. Figure 3 shows that Mahogany zone oil shale yielding 15 GPT or greater associated with low stripping ratios $(<5)$ and the thinnest overburden $(<1,000 \mathrm{ft}$, inferred from the zone isopachs and stripping ratios) is distributed along the western and southern margins of the Piceance Basin. In the eastern and southern margins of the Uinta Basin, there are expansive areas where the Mahogany zone averages $15 \mathrm{GPT}$, with zone thicknesses of about $100 \mathrm{ft}$ and stripping ratios less than 10. Figure 3 also indicates the geographic distribution of acreage containing high-grade oil shale ( $\geq 25$ GPT) within the Mahogany zone in the Piceance Basin and shows that much of the basin center contains highgrade resource that is thick (>100 ft) but is overlain by $1,000 \mathrm{ft}$ or more of overburden.

Any use of trade, product, or firm names is for descriptive purposes only and does not imply endorsement by the U.S. Government. 
A

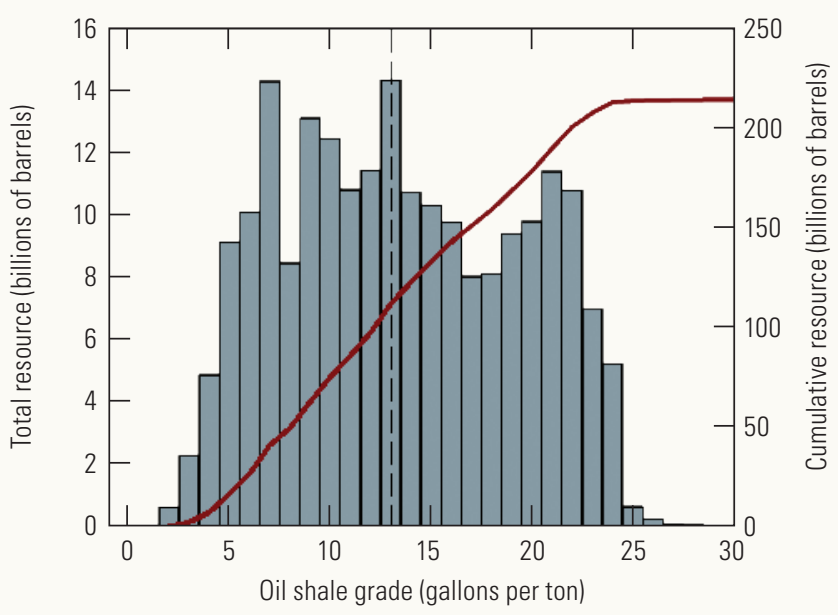

C

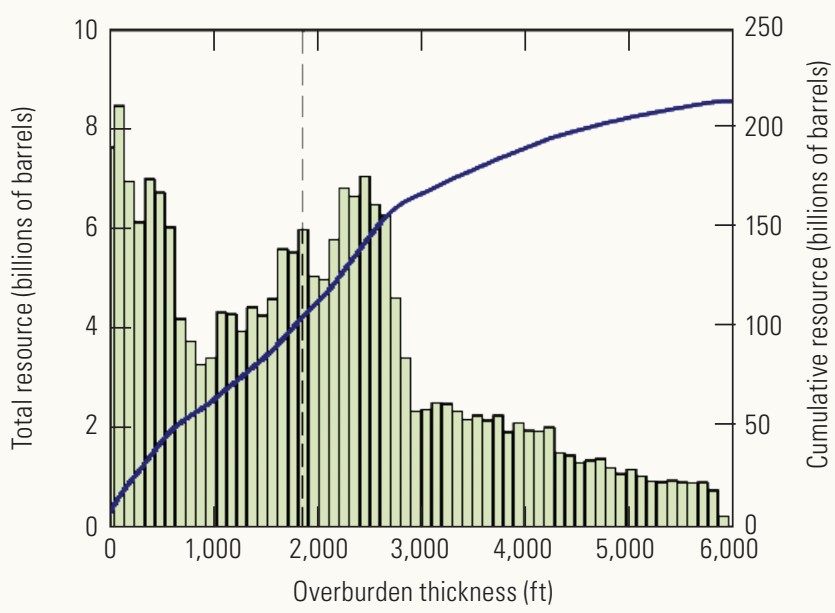

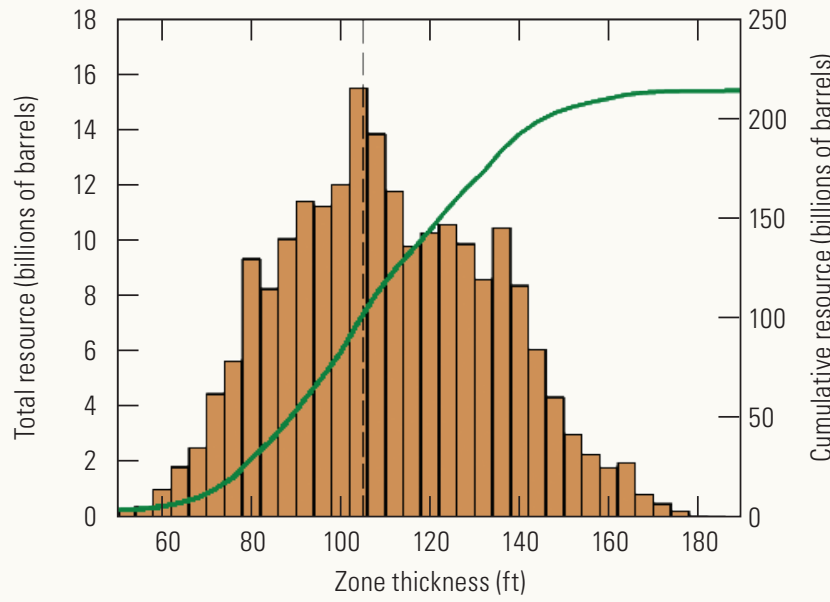

$\boldsymbol{D}$

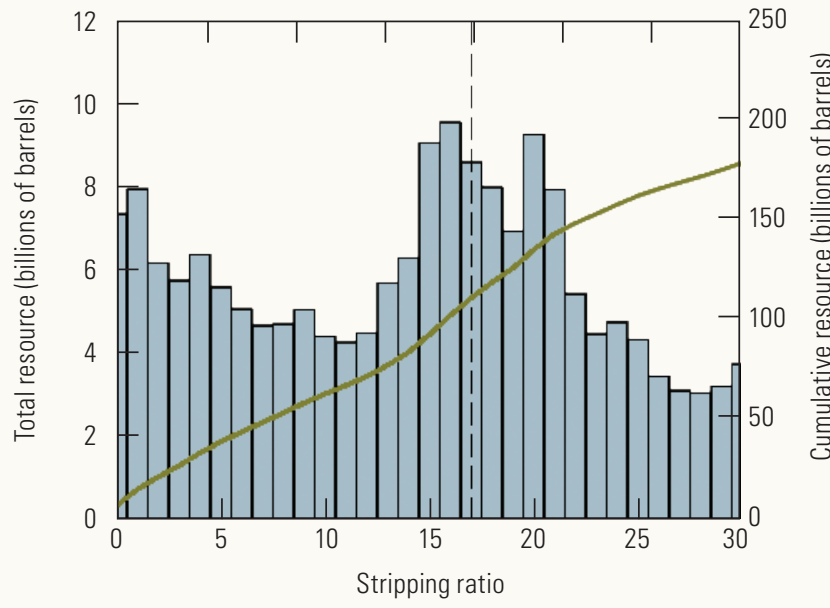

Figure 2. Histograms showing discrete (bars, left vertical axes) and cumulative (thick lines, right vertical axes) distributions of Uinta Basin oil shale resource in-place for the Mahogany zone sorted by $A$, grade (in gallons per ton); $B$, zone thickness (in feet $[\mathrm{ft}]$ ); $C$, overburden thickness (in feet); and $D$, stripping ratio. Dashed lines mark the median property value for each distribution, determined at 50 percent of the total cumulative resource of $214,547,905,331$ barrels of oil. Note that the stripping ratio distribution stops at approximately 84 percent of the total cumulative resource, which is due to the long tail of this distribution, extending to values as high as 600 . 


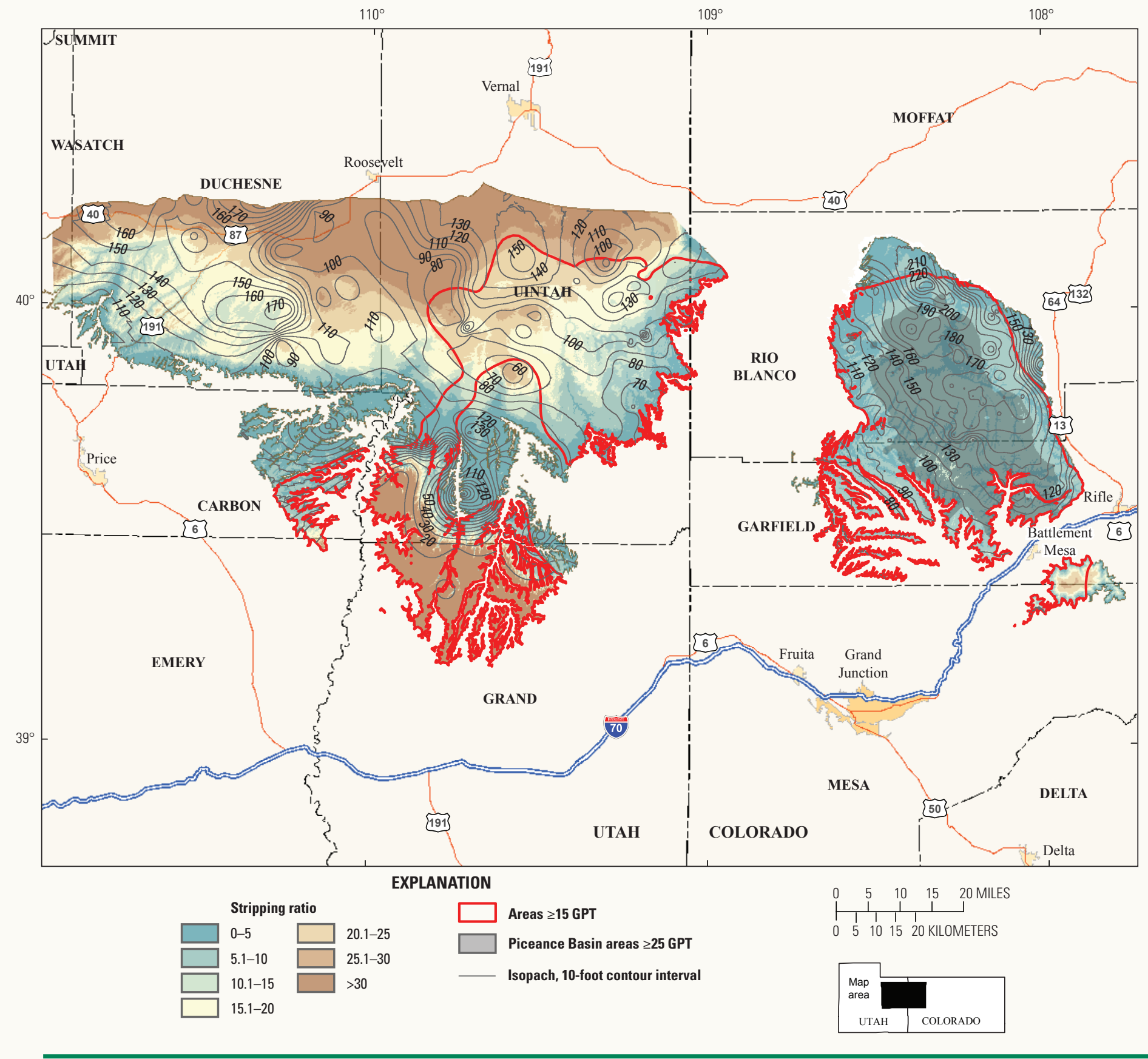

Figure 3. Map showing stripping ratio (color coded), Mahogany zone thickness (gray isopachs), 15-gallon-per-ton (GPT) area (red line), and 25-GPT area (shaded area in Piceance Basin, Colorado) for the Mahogany zone. $>$, greater than; $\geq$, greater than or equal to. 
Table 1. Oil shale resources sorted using combinations of grade, overburden thickness, and stripping ratio in the Green River Formation, Piceance Basin, Colorado, and Uinta Basin, Utah.

[Resource figures are in billions of barrels. ft, feet; GPT, gallons per ton; <, less than]

\begin{tabular}{|c|c|c|c|c|c|c|}
\hline & \multicolumn{4}{|c|}{ Piceance Basin } & \multirow{2}{*}{\multicolumn{2}{|c|}{$\begin{array}{l}\text { Uinta Basin, oil yield of } \\
15 \text { GPT or greater }\end{array}$}} \\
\hline & \multicolumn{2}{|c|}{ Oil yield of $15 \mathrm{GPT}^{1}$ or greater } & \multicolumn{2}{|c|}{ Oil yield of 25 GPT or greater } & & \\
\hline & $\begin{array}{l}\text { Oil in- } \\
\text { place }\end{array}$ & $\begin{array}{c}\text { As percentage } \\
\text { of total in-place } \\
>15 \mathrm{GPT}\end{array}$ & $\begin{array}{l}\text { Oil in- } \\
\text { place }\end{array}$ & $\begin{array}{c}\text { As percentage } \\
\text { of total in-place } \\
>25 \mathrm{GPT}\end{array}$ & $\begin{array}{l}\text { Oil in- } \\
\text { place }\end{array}$ & $\begin{array}{c}\text { As percentage } \\
\text { of total in-place } \\
>15 \mathrm{GPT}\end{array}$ \\
\hline Overburden $<500 \mathrm{ft}$; stripping ratio ${ }^{3}<5$ & 25.77 & 14.2 & 6.40 & 5.9 & 13.34 & 14.6 \\
\hline Overburden $<1,000 \mathrm{ft}$; stripping ratio $<5$ & 52.80 & 29.2 & 21.38 & 19.7 & 13.88 & 15.2 \\
\hline Overburden $<500 \mathrm{ft}$; stripping ratio $<10$ & 28.91 & 16.0 & 6.61 & 6.1 & 16.21 & 17.7 \\
\hline Overburden $<1,000 \mathrm{ft}$; stripping ratio $<10$ & 114.1 & 63.0 & 61.88 & 57.1 & 29.95 & 32.7 \\
\hline Overburden $<2,000 \mathrm{ft}$; stripping ratio $<10$ & 178.7 & 98.8 & 107.82 & 99.5 & 31.70 & 34.7 \\
\hline
\end{tabular}

${ }^{1}$ Gallons of oil per ton of rock based on Fischer assay (American Society for Testing and Materials, 1980).

${ }^{2}$ No resource in the Uinta Basin meets the 25-GPT criterion and any of the other constraints listed here.

${ }^{3}$ Stripping ratio is equal to the thickness of the overburden overlying the Mahogany zone (in feet) divided by the Mahogany zone thickness (in feet).

\section{References Cited}

American Society for Testing and Materials, 1980, ASTM D3904-90 test method for oil from oil shale (resource evaluation by the Fischer assay procedure): West Conshohocken, Pa., Annual Book of ASTM Standards [withdrawn 1996].

Bartis, J.T., LaTourrette, Tom, Dixon, Lloyd, Peterson, D.J., and Cecchine, Gary, 2005, Oil shale development in the United States-Prospects and policy issues: Prepared by the Rand Corporation for the U.S. Department of Energy, 68 p.

Baughman, G.L., 1978, Mining methods, in Synthetic fuels data handbook: Denver, Colo., Cameron Engineers, Inc., p. 51-53.

Cashion, W.B., and Donnell, J.R., 1972, Chart showing correlation of selected key units in the organic-rich sequence of the Green River Formation, Piceance Creek Basin, Colorado, and Uinta Basin, Utah: U.S. Geological Survey Oil and Gas Investigations Chart OC-65.

Donnell, J.R., and Blair, R.W., Jr., 1970, Resource appraisal of three rich oil shale zones in the Green River Formation, Piceance Creek Basin, Colorado: Colorado School of Mines Quarterly, v. 65, no. 4, p. 73-87.

Johnson, R.C., Mercier, T.J., Brownfield, M.E., Pantea, M.P., and Self, J.G., 2010a, An assessment of in-place oil shale resources in the Green River Formation, Piceance Basin, Colorado, chap. 1 of Oil shale and nahcolite resources of the Piceance Basin, Colorado: U.S. Geological Survey Digital Data Series 69-Y, 187 p.

Johnson, R.C., Mercier, T.J., Brownfield, M.E., and Self, J.G., 2010b, Assessment of in-place oil shale resources in the Eocene Green River Formation, Uinta Basin, Utah and
Colorado, chap. 1 of Oil shale resources of the Uinta Basin, Utah and Colorado: U.S. Geological Survey Digital Data Series 69-BB, 153 p.

Mercier, T.J., 2010a, Calculation of overburden above the Mahogany zone in the Piceance Basin, Colorado, chap. 6 of Oil shale and nahcolite resources of the Piceance Basin, Colorado: U.S. Geological Survey Digital Data Series 69-Y, 9 p.

Mercier, T.J., 2010b, Calculation of overburden above the Mahogany bed in the Uinta Basin, Utah and Colorado, chap. 6 of Oil shale resources of the Uinta Basin, Utah and Colorado: U.S. Geological Survey Digital Data Series 69-BB, 7 p.

Office of Technology Assessment, 1980, Chapter 9-Water availability, in An assessment of oil shale technologies, Volume I: Washington, D.C., U.S. Congress, p. 364.

Speight, J.G., 2012, Mining and retorting, in Shale oil production process: Waltham, Mass., Gulf Professional Publishing, p. $93-122$.

By Justin E. Birdwell, Tracey J. Mercier, Ronald C. Johnson, and Michael E. Brownfield

\section{For further information, contact:}

Justin E. Birdwell

U.S. Geological Survey

Denver Federal Center

Box 25046, MS 977

Denver, CO 80225

jbirdwell@usgs.gov 